\title{
Created in the Image and Likeness of God: An Exposition of Relationship in Human Creation
}

\author{
Yohanes Verdianto \\ Universitas Halmahera, Indonesia \\ yohanesvd@uniera.ac.id
}

\begin{abstract}
After God created plants, animals, and light objects, God created humans. The first man (Adam) was formed from the dust of the ground and breathed into his nostrils the breath of life to become a living man. After that, God formed a woman (Eve) from the rib of a human (Adam), both of them lived happily in their relationship with God in the garden of Eden, until finally they were tempted by the serpent and expelled from the garden of Eden. This study aims to find out what relationships exist in the Garden of Eden, from the creation of man to his fall. This paper argues that four types of relationships exist. First is the relationship between the Creator and humans, fellowship and worship by humans to God the Creator. Second, the relationship between humans and other created beings, where God's original purpose is for humans to control and manage other created beings. Third, the relationship between humans (Adam) and humans (Eve) symbolizes God's love for humans so that humans must love each other both horizontally and vertically. Fourth, the relationship between humans and snakes, where they were tempted by the serpent and were eventually expelled from the Garden of Eden, but there was a promise of redemption that God gave them. This paper uses a qualitative method with a descriptive analysis approach. The literature used is the main source regarding the fellowship between God the Creator and His human creation and the various relationships that existed in the Garden of Eden. Secondary sources are needed to compare and provide input in connection with this research.
\end{abstract}

\section{Keywords}

Image of God; creation; human, relationship; redemption

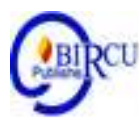

\section{Introduction}

The pinnacle of creation is when God created man. Unlike animals and plants, humans received special attention from God when they were made. God did not say "be" when he created man, as he did when he created animals and plants. He formed man "from the dust of the ground and breathed into his nostrils the breath of life" (Gen. 2:7), and Eve was created from Adam's rib (Gen. 2:21). Adam and Eve were created in the image and likeness of God (Gen. 1:26, 27).

The impression of this peak of creation is seen in the biblical record of God's declaration when he created man. There is a change in the verb that God used in the previous creation ("let there be," KJV) to ("let us make," KJV) when creating humans. (Hamilton, 1990) The animals that were created before humans have been created after their kind to look and act like their own species. This is, of course, does not apply to humans. Humans are uniquely introduced as created in the image and likeness of God. John Sailhamer explains that "Man's image is not only about himself; he also shares a resemblance to his Creator." (Sailhamer, 1990) In some ways, the man was created after 
God's own kind. In addition to this unique work, humans are defined as male and female and given dominion over the previously created animals.

If humans are created in the image and likeness of God and distinguish them from other creatures created by God, various questions and views arise regarding this matter. What is meant by "in the image and likeness of God"? Do we look like God? Are we behaving like God? Are we reflecting on God? What is the relationship between the Creator and His human creation? And what are the other relationships that exist in the creation story in the Garden of Eden? Likewise, there are many other questions regarding this matter. That's why, in order to comprehensively study the phrase "created in the image and likeness of God," this research was made.

Of course, there have been many written works regarding this matter,(Sitanggang \& Juantini, 2019); (Cherry, 2017); (Cobb-Bearden, n.d.); (Mueller, 1999); (McCasland, 1950); (Kilner, 2010); (Djadi, 2004) that's why the author will examine what was discussed earlier, which focuses more on the relationship between humans and their Creator and various other relationships that existed in the Garden of Eden from creation until humans fell into sin.

\section{Research Method}

The research was conducted using qualitative methods with a descriptive analysis approach to library data or literature. (Ridley, 2012) The literature used is the main source regarding the fellowship between God the Creator and created humans and the various relationships that existed in the Garden of Eden. Secondary sources are needed to compare and provide input in connection with this research.

\section{Results and Discussion}

This research produced biblical meanings about being created in the image and likeness of God concerning the fellowship that exists between God and man, and that distinguishes him from other creatures created by God, as well as various relationships that exist in the Garden of Eden in addition to the relationship between the Creator and His human creation. These relationships are the relationship between the Creator and man; The relationship between humans and other created beings; The relationship between humans (Adam) and humans (Eve), and the relationship between humans and snakes. It is hoped that the results of this research will make us more appreciative of life and God who gave us life so that we will better understand the meaning of our existence as living beings and social beings amid vertical and horizontal relationships.

\subsection{Created In God's Image}

God said, "Let us make man in our image and likeness" (Gen. 1:26). What does it mean to be "created in the image of God"? Do we look like God? Are we acting like God? How does God appear? In this regard, theology argues that it is called anthropomorphic, i.e., speaking of God in ways that humans can describe,(Anthropomorphic, n.d.) although it is difficult to determine specifically what the biblical writers meant by this phrase.(Crapps, 1990) But one thing is certain, as Edward Heppenstall explains, "Man was created in the image of God, not in the image of brutality."(Heppenstall, 1974)

Regarding Genesis 1:26-27, Gerhard von Rad comments it emphatically as follows: 
The creation of man is introduced more impressively than any previous creation work with the notification of the Divine resolution, "Let us make man." God participated more intimately and intensively in this than any previous work of creation. The verb bãrã' in verse 27 has full meaning for God's incomparable creative act. This word appears three times in one verse to confirm that this is the main purpose of God's creation of man.(Rad, 1961)

God created, and He is the only One who "created." The word "create" (bãrã) is exclusively used by God in the Old Testament. The man never created. According to the Scriptures, we can make, shape, carve, or build something, but we cannot create anything. Only God is the subject of the verb "create" (bãrã) in the Bible.(Johnson, 2018) God created something from nothing into existence, which is difficult for the human mind to comprehend.(Taylor, 2017) God's creation is creation ex nihilo, a doctrine taught by the Scriptures (Rom 4:7; Heb 11:3).(Neville, 2011); (Charnock \& Fuller, 1957) This ex nihilo doctrine asserts that God is the Creator of all things, and also asserts that the first creative act reported in the Bible was related to something non-existent coming into being, and then from this pre-existing matter, namely "the earth was formless and void" (Genesis 1:2), is the raw material for the next Divine creation.(Verdianto, 2020) In this regard, Walter Zimmerly emphatically states,

All creation works are introduced and called into existence based on the words of God's commandments, but the creation of man begins with a Divine reflection: "Let us make man in Our image and likeness." And the result is that man "does have dominion over the fish of the sea and over the birds of the air and over every creature that creeps on the earth."'(Zimmerli, 1976)

The creation of man, which is God's image, makes man different from other created beings. In the world of theology, there are at least three views on this matter, namely the substantial view, the functional view, and the relational view.(Erickson, 1988);(Turner, 1996); (Orr, n.d.); (Shepherd, 1988) According to the substantial view, certain human qualities reflect or describe God, such as rationality, will, compassion, and morality; namely, the psychological similarity between God and man(Erickson, 1988) and man's freedom.(Brunner, 1952)

The functional view speaks of the function of humans when created by God to dominate other creatures (Gen. 1:26-28). This can be seen from the text that says "so that they may rule ..." which appears after the sentence "Let us make humans in our image and likeness."(Eckardt, 2015) The dominance of man over animals is clearly seen when God brings animals to man to name them. Half of Genesis 2:19 emphasizes that God gave humans the gift of the power to name all the animals He created.(Carr, 2021)

\subsection{Relationships in the Creation of Man}

It cannot be denied that because humans are created differently from other created beings, where humans are made in the image of God, and formed by divine hands, there is a relationship between God and humans, a relationship that certainly does not exist in other created beings.(Maxwell, 1972) This relationship is clearly seen in Genesis 1:26, where 
humans are uniquely created because they were created in the image and likeness of God. Humans are also the only creation of God who got life by divine breath (Gen. 2:7). In the garden of Eden, only man received a direct infusion of Divine breath, a ritual act that made him able to speak and signified his assignment as someone who would talk about and for God to other creatures.(Chapman, 2019) W. Riedel says, "The image of God has the following meanings, that God and man can relate to each other, that God can speak to people and they can understand Him and answer Him."(Riedel, 1984) The intimate communication between God and man is the first type of relationship in Genesis 1:26 when God created man in His image.

\subsection{The Relationship between Creator and Creation}

The first relationship shown in the book of Genesis is the relational partnership between created humans and the Creator. This relationship is introduced in Genesis 1:26 with the statement that Adam would specifically be created in God's own image and likeness. The intimacy of this relationship was first demonstrated by God's final approval of His now finished creation as "very good" (Gen. 1:31). In the second chapter, which is devoted to developing an intimate relationship between God and man, this relationship is described with great intimacy in communication and fellowship. Humans are the only creatures whose lives are initiated by the divine breath (Gen. 2:7), unlike creatures in the animal kingdom whom God Himself does not directly inspire.(Sarna, 1989)

Since man was created from God's breath and spirit, this constellation of vocabulary binds man who was created to gain life and speak and praise God. When God breathed His breath on man, God also gave him the gift of speech, and of course, it was this ability that Adam used to praise God. The targumic translation of this verse says as follows, "And the Lord God created Adam (from) the dust of the ground and breathed into his nostrils the breath of life, and Adam became a living being, endowed with the ability to speak" (Gen. 2:7). (McNamara, 1992) So when speaking of the "breath of life," Bible commentators sometimes refer to the Mesopotamian ritual performed to revive, wash the mouth and open the mouth to speak.(Pike, 2017) God created humans in a similar two-step manufacturing process with the skilled hands of a god and animations involving mouth-to-nose contact and infusion of Divine breath. The Divine Breath exhaled into the nostrils of the clay figure animates the human being, enabling him to move, see, eat, hear, and speak.(Hurowitz, 2003)

The Garden of Eden is described as a dwelling specially designed for mankind (Gen. 2:8-9). A full supply of beautiful trees and abundant food was given to mankind (Gen. 2:9). God gave humans a territory to cultivate and communicated openly the freedoms and restrictions given to them (Gen. 2:16-17). God created a woman to complete the first man, help him, and fulfill his loneliness (Gen. 2:18, 22). The recognition of men and women of God's voice walking in the garden clearly shows that it was a custom for God to communicate with the bearers of His image, Adam and Eve (Gen. 3:8). It is the intimacy of fellowship and relationship in which God created the true human partner. Throughout Genesis 2, the author of Genesis clearly emphasizes man's relationship with the Creator as an expression of the relationship of the image of God.(Puffer, 2017) 
W. Riedel was one of the first modern theologians to support this view by saying, "It (the image of God) consists of this, that God and man can relate to each other, that God can speak to man and that they can understand Him. and answered Him."(Riedel, 1984) Victor Maag very clearly defined his position when he said, "To say that man has been created as a creature like God means that one is capable of having a relationship with the creator."(Maag \& Müller, 1955) Another theologian, Karl Barth, strongly supports this view. He said,

The meaning and purpose of God in His creation are as follows. He wills the existence of a non-divine being, and therefore his differentiation can be a real partner; capable of acting and being responsible concerning Him; where His own Divine life form is familiar; who in the form of creation, as a copy and an imitation, can be the bearer of this form of life. Humans were created as creatures like this.(Barth, 1956)

Barth further argues that "the main purpose of human creation is to fellowship with God. The first humans were created in the image of God, but only in the likeness (not exact copies) of God so that men and women would be non-divine and available for fellowship with the Almighty."(Barth, 1956) While Barth's conclusion stems from understanding that the plural "Let us make" in Genesis 1:26 is a reference to the plurality of Godheads, one can find considerable support for the relationship between God and the first human pair regardless of one's understanding of the plural in Genesis 1: 26. There is a clear development of the relationship between God and man from Genesis 2 and throughout the scriptures. Johann J. Stamm comments that "... a human being is considered as a companion of God, as a 'You' who must listen to God, whom God questions and who must answer... following the Old Testament it is appropriate to agree with Karl Barth that the meaning of the foundation of Imago Dei is that partnership, the ability to forge a relationship."(Stamm, 1959)

Adam was "you" in his conversation with God. Although this I/thou relationship is not clearly identified until Genesis chapter 2, Stamm identifies this as the consistent goal of the creation of mankind throughout Scripture. From the creation account in Genesis 2, through God's covenant, exodus, and relationship with Israel through the prophets, exile, and return to Jerusalem, and finally, through the sacrifice and second coming of His Son, Jesus Christ, a clear purpose for the creation of man must be related to God. God's sovereignty and human obedience are key roles in this relationship. Walter Brueggemann explains,

Yahweh as the Creator of mankind, and every human person is sovereign in that relationship. The human person is a creature dependent on and created for obedience. Even before any concrete content was applied to Yahweh's commandments and obedience to the human person, the categories of sovereignty and obedience were important and definite signs of man.(Brueggemann, 1997)

Brueggemann continues, "The human person is not, and cannot be sufficient for himself, but lives in conformity with the will and purpose of the one who gives and commands life."(Brueggemann, 1997) Man's significance and life force are not found in 
the autonomous agency but remain in Him, who makes life possible through the giving of breath.(Brueggemann, 1997) Humans were created for relational intimacy and partnership with God. Adam was a partner with God in conversation. God walked with men and women in the garden of Eden. The garden itself is designed to enjoy beauty and the gift of nourishment from God to man. Humans were created as relational beings, in the image of God, so that communication and interaction are possible between God and the bearer of His image or image. This means that the story of human creation is physically different from God but completely dependent on Him (cf. Ps. 104; 147; 148).(Nygaard, 2016)

\subsection{The Relationship between Humans and Other Creatures}

The second relationship introduced in Genesis 1:26 is man's relationship to all of creation. Immediately after declaring the creation of Adam in His image, God gave man the responsibility of governing creation. The key to accurately appreciating this element of God's image is acknowledging that this human being (in governing the rest of creation), is another expression of the relational essence of man.

Adam was crowned king in Eden. The beasts obeyed his rule. He was given dominion over every living creature that God created. Therefore, Adam exercised authority over them, and as the father of the nations, he named them and used his power to dominate them.(Kangwa \& Nadar, 2014) God blessed Adam and Eve with intelligence like He did not give to any other created being. He made Adam the rightful ruler over all the works of His hands. Humans created in the divine image can contemplate and appreciate God's glorious works in nature.(Nichol, 1953) But the image of God drawn through man's domination of the beasts disappeared when man sinned, and the new humanity that emerged from Noah and his sons was called to rule over the entire earth as God's image.(Dockery, 1998)

The description of Eden's story about the relationship between humans and animals is the domination of humans over animals.(Carr, 2021) In other words, the "image of God" means that man is like God and represents Him as ruler over creation. The context of Genesis 1:26-28 emphasizes man's authority over the created world. As creatures created in "God's image," Adam and Eve were God's representatives. They were to fill the earth with godly offspring and glorify Him through their reign on earth. Thus, the "image of God" gives humans an identity as rulers, which brings with it the function of ruling over other created beings,(Garris, 2021) even humans are responsible for managing and caring for this world.(Manser, 2009)

Dallas Willard explained the importance of this power when he said, "Every human being has a 'kingdom' - or 'government' - a territory uniquely our own, where our choices determine what happens. This is a truth that reaches into the deepest part of what it means to be a person."(Willard, 1988) One's ability to say something, even if it is as simple as one's body, work, or one's creative thoughts and dreams, is very important to one's personality, and a small reflection of the sovereignty of God who rules over all creation. Willard continues, "Every being without a will is by no means a person."(Willard, 1988)

The creation of Adam and the first woman, Eve, is found in the first two chapters of Genesis. The purpose of the first story (Gen. 1:26-31) is to present the first couple in their 
relationship with God and with the entire created order. It teaches that the first humans created by God - male and female - were in God's image with a special mandate to inhabit and rule over the earth. Concerning the rest of creation, the first man, on the one hand, was a part of it, created on the same day as the other land animals; on the other hand, they are clearly above it, as the pinnacle of the creative process and the only bearers of the image of God. It is clear that Adam and Eve's proper position and dignity before God and in creation is the focus of the first Genesis account, to reign over the rest of creation.(Taylor, 1988)

This power, which God has ordained, brings all creation into a relationship with mankind. Through this relationship, all creation will participate in God's covenant with man and woman. Regarding this, Brueggemann says that "There is also no doubt that all human beings are responsible for the maintenance of healthy life on this earth. Every human person is commanded by the nature of his being and to live a life for the welfare of the world."(Brueggemann, 1997) Thus, through the power given by God over this earth, humans are responsible for the welfare of all creatures on this earth for the glory of God's name. Louis Berkhof said this emphatically,

Man is represented as standing at the top of all created order. He was crowned king of the lesser creation, and was given dominion over all the lesser creatures. Because it is his duty and privilege to make all nature and all created creatures placed under his rule, submit to his will and purpose, so that he and all his glorious powers may glorify the Creator and God of the universe almighty.(Berkhof, 1938)

Such is the functional relationship of humans with other created beings, in God's domination in the Garden of Eden.

\subsection{The Relationship between Humans (Adam) and Humans (Eve)}

Genesis 1:27 says, "So God created man in his own image, in the image of God he created him; male and female He created them." This verse indicates that the creation of male and female occurred simultaneously, whereas Genesis 2:7 means that male was created before the female. To reconcile this so that we can fully understand the relationship between men (Adam) and man (Eve), we will look at it in the light of Genesis 2:7.

It is true that "man" is an ambiguous term in ancient history.(Skinner, 1910) The word sometimes refers to Adam (Gen. 2:7, 8), but sometimes also refers to mankind as a whole (Gen. 6:1).(Clines, 1990) It is only in Genesis 3:22-24 that it appears to refer to the class of mankind at one point in history when it consisted of the proper pair, Adam and Eve.(Kawashima, 2006)

The relationship that exists between human beings, is not broken until the relationship in marriage, but it continues in the relationship between parents and children. The relationship between parents and children is likened to the relationship between God and mankind, where God's role in the relationship between parents and children is as a guardian and protector.(Crouch, 2010)

\subsection{Relationship Between Man and Snake (Satan)}

Paul writes about Eve three times in his letters, in two of which he discusses Eve's role as one deceived by the serpent: first, In 2 Corinthians 11:3, Paul likened the church 
community to Eve in that they were vulnerable to the deception that could lead them astray. Secondly, In 1 Timothy 2:8-14, Paul mentions Eve in his instructions on gender roles in the church community. Thirdly, In 1 Corinthians 11:8-9, Paul also mentions Eve when discussing creation.(Bott, 2016)

Paul's particular reference to Eve as a transgressor (1 Tim. 2:14) raises questions about the content of the Genesis account in terms of later interpretation. In Genesis, Adam, Eve, and the serpent were all punished as transgressors (Gen. 3:14-19). In this case, Eve was not chosen as more guilty than Adam.(Webb, 2001)

This view differs slightly from that of some other philosophers and theologians. Philo said that Eve was inferior to Adam and that Adam had dominion over him, whereupon Eve declared that Adam was superior to her.(Philo, 2016) Some traditions choose Eve as the cause of sin and death entering the world. For example, Sirach 25:24 states, "From a woman sin began, and because of her we all died" (cf. 2 Enoch 30:17).(The Holy Bible: New Revised Standard Version, 1989)

The dialogue between Eve and the serpent in Genesis 3 shows the closeness between Eve and the serpent. Maybe this is not the first time Eve has met a snake.(Dekker, 2007) While in the garden of Eden, Adam and Eve were both naked, and in Hebrew, "naked" (arumim), and the nickname given by the Genesis writer to the serpent's wiles is "crafty" (arum). Although they differ in etymology, they look similar enough that the authors of Genesis propose a connection between the two.(Armstrong, 1996) The word "naked" here also means weak, fragile, and unprotected. This is the reason why the snake in its cunning, can deceive Eve.

If one listens to the tempter, the natural conclusion is that God cannot be trusted. Therefore, do whatever you want. And that's what Eve did in verse 6. The Bible says she took the fruit, and she ate it. He has indeed taken the fruit but notices that something happened to his head or heart before he took the forbidden fruit. By the time he took the fruit, he had sinned. In essence, he had conveyed to God to leave him alone, that he knew better than He did what was good for him. He has rejected His Word and will and replaced it with his own wisdom and will. In short, before reaching for the fruit, Eve had chosen her own will over the will of God. He has placed himself on the throne of his life, at the center of his universe, thereby replacing God. In fact, he had focused his love on himself rather than on God. And that is the essence of sin.(Knight, 2001)

When our first ancestors sinned, their disobedience to God alienated them from God and one another.(Dockery, 1998) Nevertheless, God promised the Savior when He said to them, "I will put enmity between you and this woman, between your seed and her seed; his offspring will crush your head, and you will crush his heel" (Gen 3:15). Regarding this, Dockery continues that "The Fall means that we humans are prone to sin. Although God punishes sin, sin does not thwart God's ultimate purpose and grace for His human creation. Within the curse lies the radiance of the promise that the offspring of that woman will one day lead mankind to victory."(Dockery, 1998) 


\section{Conclusion}

Based on the research conducted on the relationship that emerged in the garden of Eden, from the creation to the fall of man in terms of the phrase created in the image and likeness of God, four relationships arise that are related to each other and lead to a fellowship between the Savior and sinful mankind. First, because the man was created in the image and likeness of God, man should reflect God's image in his life. Through close fellowship with God, humans can still display the image of God in their daily lives, even though they have fallen into sin. Second, God's immediate reason for creating man was for man to have dominion over other creatures. This is clearly seen when God brings animals to be named by humans. This domination does not make humans arbitrary towards the animal world but rather manages other creatures who are also God's creations.

Third, the relationship that exists between humans (Adam) and humans (Eve), in which they must show each other love, care, fellowship, and at the same time establish a relationship with their Creator God. This loving relationship boils down to a holy marriage, where they can express God's love for their children. So this relationship is not only horizontal but also vertical. Fourth is the relationship that arose between Eve and the serpent. When the serpent succeeded in tempting Eve to sin, Eve became Satan's agent to persuade Adam to sin too. But the good news is God promised a Savior who would deliver them from the chaos of sin and put an end to sin and the wages of sin. Finally, the relationship that started in the Garden of Eden is back, humans and their Creator.

\section{References}

Anthropomorphic. (n.d.). Retrieved May 10. (2021). from https://www.merriamwebster.com/dictionary/anthropomorphic.

Armstrong, K. (1996). In the Beginning: A New Interpretation of Genesis. Alfred A. Knopf.

Augustine. (1988a). Confessions: Nicene and Post-Nicene Fathers (Philip Schaff (Ed.)). Eerdmans.

Augustine. (1988b). De Trinitatis. In P. Schaff (Ed.), Nicene and Post-Nicene Fathers. Eerdmans.

Bal, M. (1987). Lethal Love Feminist Literary readings of Biblical Love Stories.

Barr, J. (1968). The image of god in the book of genesis: A study of terminology. Bulletin of the John Rylands Library, 51(1), 11-26.

Barth, K. (1956). Church Dogmatics. T\&T Clark.

Berkhof, L. (1938). Systematic Theology. Wm. B. Eerdmans.

Bird, P. A. (1981). "Male and Female He Created Them": Gen 1: 27b in the Context of the Priestly Account of Creation1. Harvard Theological Review, 74(2), 129-160.

Bird, P. A. (1994). Genesis 3 in modern biblical scholarship. Missing Persons and Mistaken Identities, 174-193.

Bott, N. (2016). Eve. In J. D. B. et al (Ed.), Lexham Bible Dictionary. Lexham Press.

Brueggemann, W. (1997). Theology of the Old Testament. Fortress Press.

Brunner, E. (1948). Man in Revolt. Westminster Press.

Brunner, E. (1952). The Christian Doctrine of Creation and Redemption: Dogmatics. Lutterworth Press.

Carr, D. M. (2021). Competing Construals of Human Relations with "Animal" Others in the Primeval History (Genesis 1-11). Journal of Biblical Literature, 140(2), 251-269.

Chapman, C. R. (2019). The Breath of Life: Speech, Gender, and Authority in the Garden 
of Eden. Journal of Biblical Literature, 138(2), 241-262.

Charnock, S., \& Fuller, A. (1957). The Bible: Text of the Month. Christianity Today, $1(22)$.

Cherry, M. J. (2017). Created in the image of God: Bioethical implications of the Imago Dei. Christian Bioethics: Non-Ecumenical Studies in Medical Morality, 23(3), 219233.

Clines, D. J. A. (1968). The image of God in man. Tyndale Bulletin, 19(53), 103.

Clines, D. J. A. (1990). What does Eve do to help: And other readerly questions to the Old Testament (Vol. 94). A\&C Black.

Cobb-Bearden, L. A. (n.d.). CLED700-B02.

Craigie, P. C. (1983). Psalm 1-50: Word Biblical Commentary. Word.

Crapps, R. W. (1990). Mercer Dictionary of the Bible. In Mercer Dictionary of the Bible. Mercer University Press.

Crouch, C. L. (2010). Genesis 1: 26-7 as a statement of humanity's divine parentage. Journal of Theological Studies, 61(1), 1-15.

Dekker, S. W. A. (2007). Eve and the serpent: A rational choice to err. Journal of Religion and Health, 46(4), 571-579.

Djadi, J. (2004). Gambar dan Rupa Allah. Jurnal Jaffray, 2(1), 3-8.

Dockery, D. S. (Ed.). (1998). Holman Concise Bible Commentary. Broadman \& Holman Publishers.

Eckardt, B. F. (2015). Another Look at Imago Dei: Fulfilled in the Incarnate One. Concordia Theological Quarterly, 79(1/2), 67-78.

Erickson, M. J. (1988). Christian Theology. Baker.

Garris, Z. (2017). The Image of God - Fallen and Restored: Knowing Scripture.

Garris, Z. (2021). The Image of God - Fallen and Restored: Knowing Scripture. https://knowingscripture.com/articles/the-image-of-god-fallen-and-restored

Gudbergsen, T. (2012). God consists of both the Male and the Female Genders: A short note on Gen 1: 27. Vetus Testamentum, 62(3), 450-453.

Hamilton, V. P. (1990). The Book of Genesis Chapters 1-17: The New International Commentary on the Old Testament. Eerdmans.

Henry, M., \& Scott, T. (1997). Matthew Henry's Concise Commentary. Logos Research Systems.

Heppenstall, E. (1974). Salvation Unlimited: Perspectives in Righteousness by Faith. Review and Herald.

Hurowitz, V. A. (2003). The Mesopotamian god image, from womb to tomb. Journal of the American Oriental Society, 123(1), 147-157.

Jarick, J. (1990). Gregory Thaumaturgos' Paraphrase of Ecclesiastes. Scholars Press.

Johnson, D. (2018). The Universal Story: Genesis 1-11 (C. G. Bartholomew, D. Beldman, D. Mangum, J. Wilcox, \& D. Thevenaz (Eds.)). Lexham.

Kaiser Jr, W. C. (2009). The promise-plan of God: a biblical theology of the Old and New Testaments. Zondervan Academic.

Kangwa, J., \& Nadar, S. (2014). RETRACTED: Demythologizing for Ecological Justice: An African Eco-Feminist Reading of Genesis 1-3. Journal for the Study of Religion, 27(2), 270-296.

Kawashima, R. S. (2006). A revisionist reading revisited: On the creation of Adam and then Eve. Vetus Testamentum, 56(1), 46-57.

Keil, C. F., \& Delitzsch, F. (1986). Proverbs, Ecclesiastes, Song of Solomon,” Commentary on the Old Testament in Ten Volumes. Eerdmans.

Kilner, J. F. (2010). Humanity in God's image: is the image really damaged? Journal of the 
Evangelical Theological Society, 53(3), 601.

Knight, G. R. (2001). I used to be perfect: A Study of Sin and Salvation. Andrews University Press.

Maag, V., \& Müller, H.-P. (1955). Alttestamentliche Anthropogonie in ihrem Verhältnis zur altorientalischen Mythologie.

Manser, M. H. (2009). Dictionary of bible themes: The accessible and comprehensive tool for topical studies. London: Martin Manser.

Maxwell, M. J. (1972). In the 'Image'and 'Likeness' of God. Journal of Biblical Literature, 91, 289-304.

McCasland, S. V. (1950). "The Image of God" According to Paul. Journal of Biblical Literature, 85-100.

McNamara, M. S. (1992). Targum Neofiti 1: Genesis. Liturgical Press.

Mueller, C. (1999). What it means to be created in the image of God.

Najman, H. (2021). Imitatio Dei and the Formation of the Subject in Ancient Judaism. Journal of Biblical Literature, 140(2), 309-323.

Neville, R. (2011). Differentiation in Genesis 1: An Exegetical Creation ex nihilo. Journal of Biblical Literature, 130(2), 209-226.

Nichol, F. (Ed.). (1953). The Seventh-day Adventist Bible Commentary, vol. 1. Review and Herald.

Nygaard, M. (2016). Theology of Humanity. In D. J. D. Barry (Ed.), the Lexham Bible Dictionary. Lexham Press.

Orr, J. (n.d.). Image of God. In International Standard Bible Encyclopedia.

Philo. (2016). On the Creation of the World. In J. D. B. et al (Ed.), The Lexham Bible Dictionary. Lexham Press.

Pike, D. M. (2017). The Latter-day Saint Reimaging of" the Breath of Life"(Genesis 2: 7). BYU Studies Quarterly, 56(2), 71-104.

Pretorius, M. (2011). The creation and the fall of Adam and Eve: Literal, symbolic, or myth? Conspectus: The Journal of the South African Theological Seminary, 12(09), $161-184$.

Puffer, M. (2017). Human Dignity after Augustine's Imago Dei: On the Sources and Uses of Two Ethical Terms. Journal of the Society of Christian Ethics, 37(1), 65-82.

Rad, G. von. (1961). Genesis: A Commentary. Westminster Press.

Ridley, D. (2012). The literature review: A step-by-step guide for students.

Riedel, W. (1984). Die Gottesenebnildlichkeit des Menschen: Alttestamentliche Untersuchungen. In Genesis 1-11. Augsburg Publishing House.

Sailhamer, J. (1990). Genesis: The Expositor's Bible Commentary (F. E. Gaebelein (Ed.)). Zondervan.

Sarna, N. M. (1989). The JPS Torah Commentary, Genesis. Jewish Publication Society.

Shapiro, D. S. (1963). "The Doctrine of the Image of God and" Imitatio Dei. Judaism, 12(1), 57.

Shepherd, N. (1988). Image of God. In Baker Encyclopedia of the Bible. Baker Book House.

Sitanggang, M. H., \& Juantini, J. (2019). Citra Diri Menurut Kejadian 1: 26-27 dan Aplikasinya Bagi Pengurus Pemuda Remaja GPDI Hebron-Malang.

Skinner, J. (1910). A critical and exegetical commentary on Genesis (Vol. 1). T. \& T. Clark.

Stamm, J. J. (1959). Die Gottebenbildlichkeit des Menschen im Alten Testament. Theologische Studien.

Taylor, S. (1988). Adam (Person). In Baker Encyclopedia of the Bible, vol. 1. Baker Book 
House.

Taylor, S. (2017). Brand New: A 40-Day Guide to Life in Christ. Lexham Press.

The Holy Bible: New Revised Standard Version. (1989). Thomas Nelson Publishers.

Trible, P. (1973). Depatriarchalizing in biblical interpretation. Journal of the American Academy of Religion, 41(1), 30-48.

Trible, P. (1978). God and the Rhetoric of Sexuality (Vol. 2). Fortress Press.

Turner, D. L. (1996). Image of God. In W. A. Elwel (Ed.), Baker Theological Dictionary of the Bible. Baker Books.

Verdianto, Y. (2020). Penciptaan Alkitabiah dan Evolusi: Berbagai Upaya untuk Merekonsiliasi Keduanya. KHARISMATA: Jurnal Teologi Pantekosta, 3(2), 102116.

Verhoef, A. H. (2013). The relation between creation and salvation in the Trinitarian theology of Robert Jenson. HTS Teologiese Studies/Theological Studies, 69(1).

Walton, J. H. (2015). The Lost World of Adam and Eve: Genesis 2-3 and the Human Origins Debate. InterVarsity Press.

Webb, W. J. (2001). Slaves, women \& homosexuals: Exploring the hermeneutics of cultural analysis. InterVarsity Press.

Weyermann, M. (2002). The typologies of Adam-Christ and Eve-Mary, and their relationship to one another. Anglican Theological Review, 84(3), 609.

Willard, D. (1988). The Divine Conspiracy. Harper.

Wright, J. S. (1991). Ecclesiastes: The Expositor's Bible Commentary. Eerdmans.

Zimmerli, W. (1976). The Old Testament and the World. SPCK. 